\title{
High tech startup creation for energy efficient built environment
}

\author{
F. Pacheco-Torgal \\ C-TAC Research Unit, University of Minho, 4800-058 Guimarães, Portugal
}

\section{A R T I C L E I N F O}

\section{Keywords:}

Civil engineering

patents

startups

energy efficiency

built, environment

nanotechnology

biotechnology

\begin{abstract}
A B S T R A C T
The civil engineering area has long been known for not being associated with high tech startup creation. This is a sign of the low innovation which is confirmed by its low patenting level thus contributing to undermine the prestige of this area. Still this area has an important role to play given the environmental impacts of the construction industry that will be exacerbated in the next decades due to the growth in world population, each day there are about 220,000 new inhabitants which means more than 9,7 billion people by 2050 and 11,2 billion by 2100 . A direct consequence of such growth relates to a steady increase of energy consumption which is the source of two-thirds of global greenhouse-gas emissions. The building sector is responsible for high energy consumption and its global demand is expected to grow in the next decades. Between 2010 and 2050 the global heating and cooling needs are expected to increase $70 \%$ in residential buildings and $90 \%$ in commercial buildings. Major energy efficiency measures are therefore crucial to reduce energy consumption and greenhouse-gas emissions of the building sector. This includes development of new technologies and materials to improve greatly energy efficiency. Since information derived from knowledge is critical for individuals to transform innovative ideas into commercial products and services, this paper reviews recent developments on nano and bio based innovations important for an energy efficient built environment. This review may contribute to enhance the innovation and patenting activity in civil engineering. This may help to foster the creation of high tech startups for an energy efficient built environment.
\end{abstract}

\section{Introduction}

Civil engineering is known as an area mainly concerned with directing the great sources of power in Nature to the use and convenience of man trough the construction of large and public infrastructures (bridges, dams, airports, highways, tunnels etc etc etc) by large construction companies. This area has never been associated with high tech startup creation. This is a sign of the low innovation level which is confirmed by its low patenting level. In the USA the patenting level on civil engineering falls behind other areas [1]. According to Keefe [2] very few civil engineers take their innovations to the United States Patent and Trademark Office (USPTO), in contrast with the considerable number of electrical and mechanical engineers. This author provides data that show that the patenting in civil engineering area is 7 times less than in mechanical engineering and 10 times less than in electrical engineering. A recent and worldwide study [3] confirms the prone patenting nature of other more innovative areas than civil engineering. This low innovation level undermines the prestige of civil engineering and contributes to explain the reduction in undergraduate applications to civil engineering courses [4-8]. Nedhi [9] stated that civil engineering is not traditionally viewed as "high tech" engineering. Even in India this area is viewed as a low tech one [10]. As a consequence low starting salaries are normal in this area [11]. As construction enterprises have low productivity [12] they have to compete for lower bids with consequent lower profit margins [13]. They also have to cope with an increasing and fierce Chinese competition already capable of building a 30-story in just 15 days [14] which means that construction enterprises will in future have less and less financial possibilities to offer high and attractive pay checks to civil engineers. Nevertheless, civil engineering has an important role to play given the environmental impacts of the construction industry that will be exacerbated in the next decades due to the growth in world population. Urban human population will almost double, increasing from approximately 3.4 billion in 2009 to 6.4 billion in 2050 [15] and recent estimates on urban expansion suggest that until 2030 there is a high probability (over 75\%) that urban land cover will increase by 1.2 million $\mathrm{km}^{2}$ [16]. Redirecting the focus of civil engineering from the construction and rehabilitation of grand infrastructures to high tech built environment related areas and the needs of individual home users will enlarge the number of future potential clients creating a market that may foster high tech startup creation. Information derived from knowledge is critical for individuals to transform innovative ideas into commercial products and services. Distinguished Prof. Willian Baumol [17] has stated that promoting

E-mail address: torgal@civil.uminho.pt. 
entrepreneurship and small firms would play a critical role for economic prosperity. Also in the current context of high graduated unemployment rates that will be more dramatic in the next decades $[18,19]$, start-up creation could become a way to solve this serious problem. This paper reviews recent developments on nano and bio based materials and technologies. These can not only contribute to a more eco-efficient construction industry but also to enhance the innovation and patenting activity in the field of civil engineering creating a knowledge context important for entrepreneurship. This review may contribute to enhance the innovation and patenting activity in civil engineering. This may help to foster the creation of high tech startups for energy efficient built environment.

\section{The future of civil engineering on the context of sustainable development}

An important sustainable development serious problem which is directly related to the field of civil engineering concerns resource inefficiency. Over the 20th century, the world increased its fossil fuel use by a factor of 12, whilst extracting 34 times more material resources [20]. During the last century, materials use increased 8-fold and, as a result, Humanity currently uses almost 60 billion tons (Gt) of materials per year [21]. The most important environmental threat associated to its production is not so much the depletion of nonrenewable raw materials [22], but the environmental impacts caused by its extraction - namely extensive deforestation and top-soil loss, instead. In 2000, the mining worldwide activity generated $6000 \mathrm{Mt}$ of mine wastes to produce just $900 \mathrm{Mt}$ of raw materials [23]. This means an average use of only $0.15 \%$, resulting in vast quantities of waste, whose disposal represents an environmental risk in terms of biodiversity conservation, air pollution and contamination of water reserves. Since materials demand will double in the next 40 years, the environmental impacts will therefore increase in a drastic manner [20]. The global construction industry consumes more raw materials (about $3000 \mathrm{Mt} /$ year, almost $50 \%$ by weight) than any other economic activity, which emphasizes its unsustainable character. For instance, concrete is the most widely-used construction material on Earth, currently used at a level of about $10 \mathrm{~km}^{3} /$ year [24], compared to $2 \mathrm{~km}^{3}$ of fired clay, $1.3 \mathrm{~km}^{3}$ of timber, and $0.1 \mathrm{~km}^{3}$ of steel (Flatt et al. [25]) [24]. These astonishing figures show the importance of concrete in the context of material efficiency. Additionally this industry is associated to massive carbon dioxide gas emissions. The main binder of concrete, Portland cement, is responsible for almost $80 \%$ of the total $\mathrm{CO}_{2}$ emissions from concrete, which in turn make up around 6 to $7 \%$ of the planet's total $\mathrm{CO}_{2}$ emissions [25]. This is particularly serious in the light of the current concerns around climate change. It's important to mention that 2016 was the first year with atmospheric $\mathrm{CO}_{2}$ concentrations above $400 \mathrm{ppm}$ all year round (Betts et al. [140]) and, more worryingly still, the fact that the demand for Portland cement is expected to increase by almost 200\% between 2010 and 2050, reaching a level of 6000 million tons/year [26]. Also, in the next years the construction industry will keep on growing at a fast pace. China will need 40 billion square meters of combined residential and commercial floor space over the next 20 years - equivalent to adding one New York City every two years [27]. In the US, where about $27 \%$ of all highway bridges are in need of repair or replacement, the needs for infrastructure rehabilitation alone are estimated to be over 1.6 trillion dollars in the next five years [28]. Between 2012 and 2017, India will invest 1 trillion dollars in infrastructures [10]. In Europe, UK's infrastructure will need over 65-80 billion dollars every year, between now and 2030 in order to maintain current levels of service [29]. Another very important issue concerns energy consumption that has been steadily rising in the last decades (Fig. 1) and will keep on rising no matter what [31]. This is due not only to the increase in world population but also to the fact that electricity consumption per capita in low and middle income countries will increase as a consequence of

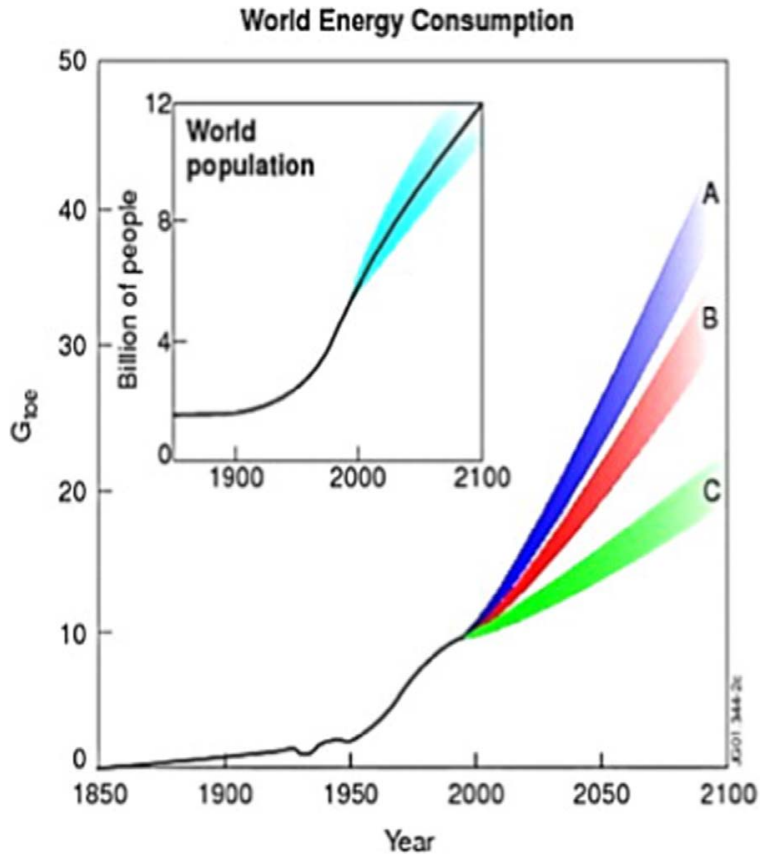

Fig. 1. World energy consumption in the past 150 years [30].

future higher income and related higher comfort standards. This is aggravated by the fact that only $21 \%$ of world electricity generation was from renewable energy in 2011 with a projection for nearly $25 \%$ in 2040 [32]. As the source of two-thirds of global greenhouse-gas emissions, the energy sector is therefore pivotal in determining whether or not climate change goals are achieved. Climate change is one of the most important problems faced by the Human species being associated to the rise in the sea level, ocean acidification, heavy rain, heat waves and extreme atmospheric events, environment deterioration and wildlife extinction, health problems and infrastructure damage [33]. The building sector is responsible for high energy consumption and its global demand is expected to grow in the next decades. Between 2010 and 2015 the global heating and cooling needs are expected to increase by $70 \%$ in residential buildings (Fig. 2a) and $90 \%$ in commercial buildings (Fig. 2b). Energy efficiency measures are therefore crucial to reduce GHG emissions of the building sector. Recent estimates [35] state that energy efficiency concerning buildings heating and cooling needs could allow a reduction between 2-3.2 $\mathrm{GtCO}_{2} \mathrm{e}$ per year in 2020. In Europe, buildings are responsible for more than $40 \%$ of the energy consumption and greenhouse gas emissions [36] and the average energy efficiency improvement at EU level, fell from $14 \%$ in the period $2000-2008$ to $6 \%$ in the years $2008-2013$ [37]. Fig. 3 shows the energy efficiency trends for households in several EU countries. The recasting of the Energy Performance of Buildings Directive (EPBD) was adopted by the European Parliament and the Council of the European Union on 19 May 2010. The recast set 2020 as the deadline for all new buildings to be 'nearly zero energy'; for public buildings, however, the deadline is even sooner - by 2018. Come what may, the fact is that new buildings have limited impacts on overall energy reduction as they represent just a tiny fraction of the existing building stock [38]. This shows the importance of building retrofitting for attaining ambitious energy efficiency goals. Building energy efficiency retrofitting is also crucial to tackle the important social problem of energy poverty. This problem affects between 1.3 billion and 2.6 billion people from underdeveloped regions of the world. Between 50 and 125 million people in Europe alone suffer from energy poverty [39]. This has important health consequences for children and older people leading to an increase in medical costs. Infants, living in energy poor homes are associated with a $30 \%$ greater risk of admission to hospital care. Indoor cold is also highly correlated to premature 

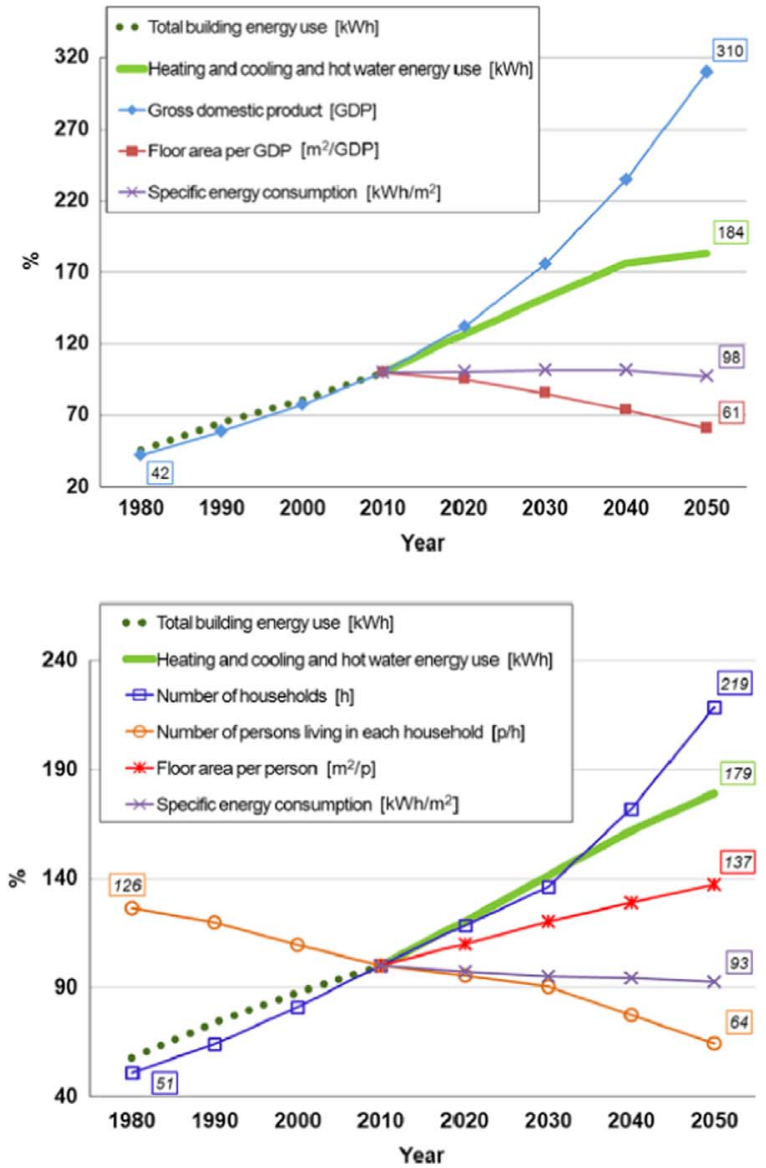

Fig. 2. Trends in the different drivers of energy consumption in residential (a) and commercial buildings (b) in the world 1980-2050 [34].
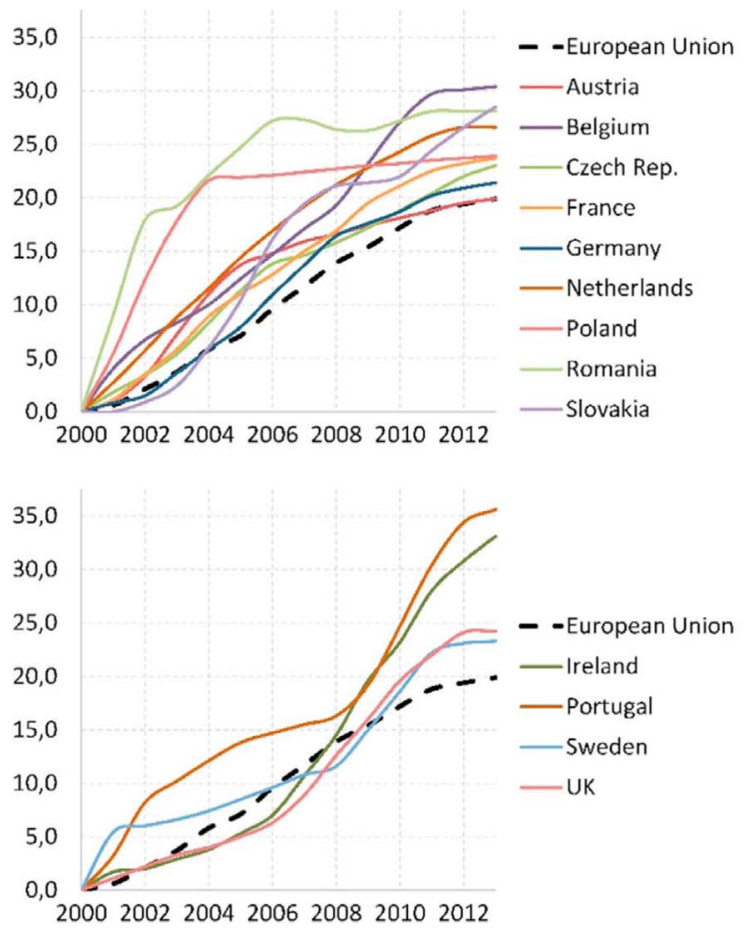

mortality. Between $30 \%$ and $50 \%$ of excess winter mortality is attributed specifically to energy-inefficient housing conditions. Besides, direct financial help to low income households or the use of energy subsidies can only tackle this problem in a partial manner without solving it in a long term, while the funding of building energy efficiency refurbishment works are also able to generate added value and economic growth [39]. Renovating existing buildings is therefore a 'win-win' option for the EU economy. Energy renovation is also instrumental in reaching the EU 2020 goals having implications for growth and jobs, energy and climate and cohesion policies [40]. Numerous financing instruments exist at the EU level an important share being devoted to low carbon investments by the EU, European Investment bank (EIB) and various EU stakeholders [41].

\section{Nanotechnology opportunities for energy efficient built environment}

Nanotechnology is a hot topic in current research, defined by Drexler [42] as the manufacture of products using dimensions and precision between 0.1 and $100 \mathrm{~nm}\left(1 \mathrm{~nm}=1 \times 10^{-9} \mathrm{~m}\right)$. The author agrees with Zheng et al. [43] when they state that nanotechnology could also help to convey a new vision for civil engineering. It is a hot area with an amazing growth potential. So far, more than 2,000,000 articles related to nanotechnologies have been published, and over $1,000,000$ applications are lodged in patent offices [44]. Dozens of countries have already designed national strategies and have begun to implement national nanotechnology plans $[45,46]$. Countries are trying to establish an advantageous position 'so that when nanotech applications begin to have a significant impact in the world economy, countries are able to exploit these new opportunities to the full' [47]. Europe assigned 4.865 billion euros to 'Nanosciences, Nanotechnologies, Materials and new Production Technologies' as part of the 7th Framework Programme for the 2007-2013 period. In the United States, a dedicated nanotechnology act was signed into a law, which set aside 3.679 billion dollars of funding for the 2005-2008 period [48]. China has identified nanotechnology as a priority area in its national agenda of science and technology development (2006-
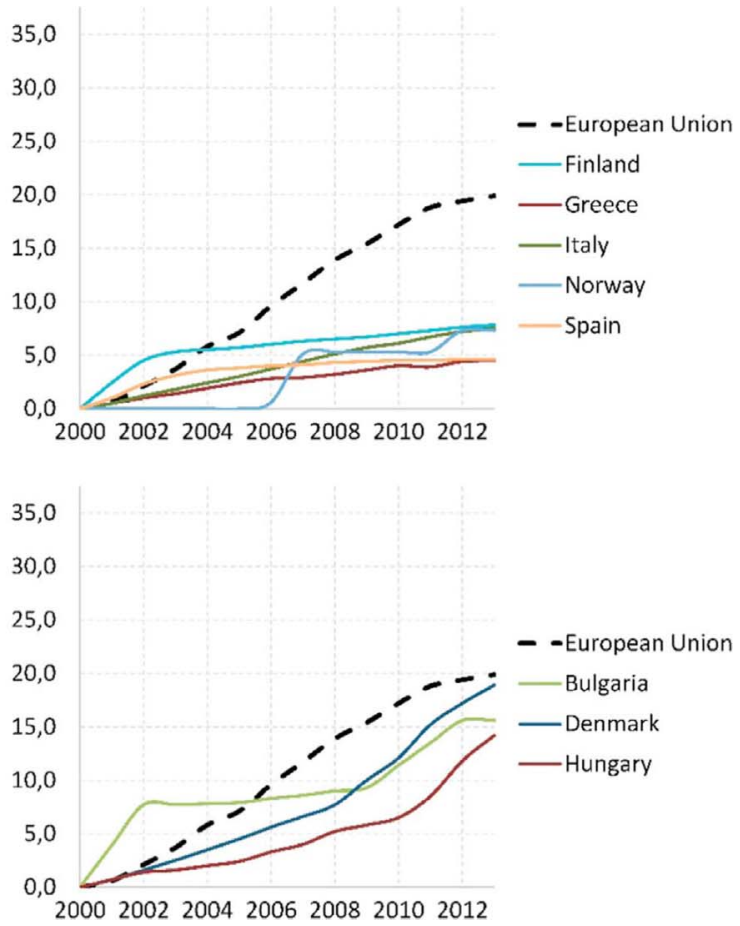

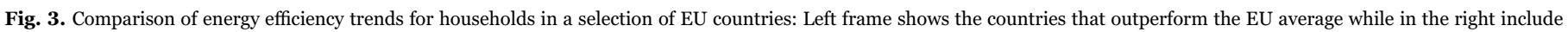
those below energy efficiency average [37]. 

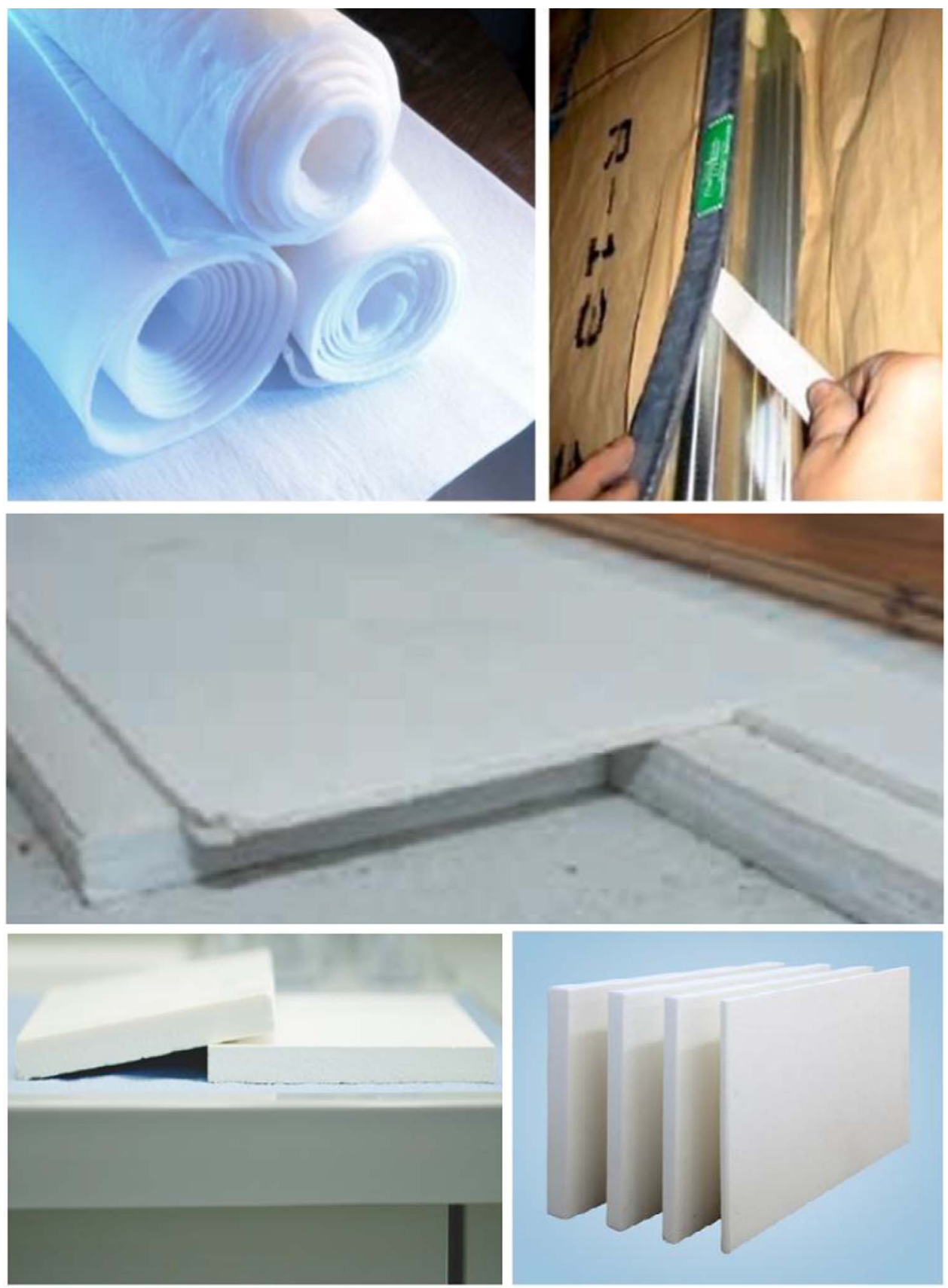

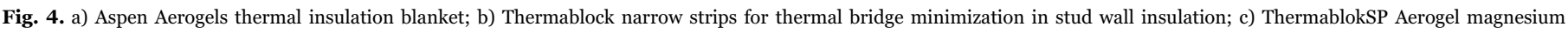
flooring borads; d) SLENTITE high-performance organic insulation board; e) Sto- Aevero ultra interior insulation panel [68].

2020), and has increased R \& D investment in the field. In fact, China has consequently emerged as one of the key global players in nanotechnology, producing the second largest number of nanotechnology papers after United States [49]. China has made significant advances and currently has the fastest growing nanotechnology publications. However it still lags behind publication on leading nanotechnology journals. An analysis of papers published in nano related journals with an impact factor above 20, shows that USA published 1068 papers, Germany (221), UK (193), France (149), Japan (121) and China only produced 76 papers [50]. Of course this may change in the coming future because the Chinese one-thousand-talents plan (www. 1000plan.org) to attract its overseas researchers has already recruited more than 2000 researchers most of them trained in the USA [51]. According to Serrano et al. [52] nanotechnology offers, for the first time, tools to develop new industries based on cost-effective and cost- efficient economies, thus seriously contributing to a sustainable economic growth. However, Shapira and Youtie [53] mentioned that many sales forecasts were adjusted downwards because some of the promised scale benefits are unlikely to be realized. On one hand the LCA of complex nanomaterials may not be very environmental friendly and may require further investigations. Up to this date the recyclability of nanomaterials is not being adequately tackled, as well as their environmental impacts in the end-of-life stage $[54,55]$. On the other hand the toxicity of various nanomaterials for human health and for the environment is still under debate (Kim et al. [56]). Safety management of nanoparticles and nanomaterials is also a critical issue [57]. Lopez de Ipina et al. [58] has recently disclosed results of the European project SCAFFOLD that has addressed itself to the risk management regarding the handling of nanomaterials in the construction sector. Those issues are very important because a few 
Table 1

Price of conventional plasters [73]

\begin{tabular}{|c|c|c|c|c|c|}
\hline Product & Type & Thermal conductivity $(\mathrm{W} / \mathrm{mK})$ & Price (euro/m2 Rx for $\mathrm{s}=10 \mathrm{~mm}$ ) & Thickness $\mathrm{R}_{\mathrm{x}}(\mathrm{mm} / \mathrm{m} 2)$ & Price $\left[€ / s q m R_{x}\right]$ \\
\hline 1 & Cement based plaster & 0.055 & 3,590 & 55.0 & 19.75 \\
\hline 2 & & 0.090 & 5,437 & 90.0 & 48.94 \\
\hline 3 & & 0.074 & 3,700 & 74.0 & 27.38 \\
\hline 4 & & 0.056 & 4,440 & 56.0 & 24.64 \\
\hline 5 & & 0.09 & 5,200 & 90.0 & 46.80 \\
\hline 6 & & 0.062 & 3,520 & 62.0 & 21.82 \\
\hline 7 & & 0.075 & 4,587 & 75.0 & 34.40 \\
\hline 8 & Cement based plaster & 0.111 & 10,840 & 111.0 & 120.32 \\
\hline 9 & Lime based plaster & 0.2 & 11,500 & 200.0 & 230.00 \\
\hline 10 & & 0.075 & 8,550 & 75.0 & 64.13 \\
\hline 11 & & 0.060 & 4,800 & 60.0 & 28.80 \\
\hline 12 & & 0.091 & 5,840 & 91.0 & 53.14 \\
\hline 13 & & 0.066 & 11,080 & 66.0 & 73.13 \\
\hline 14 & Lime based plaster & 0.088 & 5,360 & 88.0 & 47.17 \\
\hline 15 & $\begin{array}{l}\text { Aerogel based plaster } \\
\text { Fixit } 222\end{array}$ & 0.028 & 80.0 & 28.00 & 224.00 \\
\hline
\end{tabular}

years ago the European Union passed regulations concerning the environmental performance of materials used in the built environment. On 9 March 2011 the European Union approved Regulation (EU) 305/2011, the -Construction Products RegulationCPR, that replaced Directive 89/106/EEC, already amended by Directive 1993/68/EEC, known as the Construction Products Directive (CPD). When comparing the basic requirements of the CPR and CPD, one can see that the CPR has a new requirement, no. 7 (Sustainable use of natural resources), and also that no. 3 (Hygiene, health and the environment) and no. 4 (Safety and accessibility in use) have been refined. Meaning that since 1 of July 2013 environmental assessment of construction materials in Europe is mandatory for its commercialization. Very few nanotech applications are currently in use in the construction sector which, in fact, seems to have been somewhat neglected by nanotech research to this date $[59,60]$. A search for the terms 'nanotechnology' and eco-efficient construction in journals listed in Scopus has revealed only around thirty papers, half of those are related to cement and concrete. Nanotech research is, therefore, crucial in helping to identify methods of making concrete more environmentally friendly. Consequently, the construction industry should also be at the core of the R\&D efforts in nanotechnology which, as one of the largest and most active sectors in the world, will continue to grow at a rapid pace over the coming decades. As already mentioned, building energy efficiency is an issue of crucial importance. Weinberger et al. [61] compared several environmental technologies mentioning that the highest market potentials were measured for technologies in building energy efficiency. The global market for energy efficient building will go from 68 billion dollars in 2011 to surpassing 100 billion dollars by 2017. More recent estimates forecast that nanotechnology based products for renewable energy will generate as much as 2.5 trillion dollars (Hussein [62]). An important area that can benefit from nanotechnology research efforts concerns energy efficiency of the built environment. The development of new technologies and materials to greatly improve energy efficiency [63] are of utmost importance. Aerogel is a perfect example of a high performance thermal insulation material and according to Jelle "may be the most promising with the highest potential of them all at the moment" [64]. Aerogel was invented by Samuel Kistler in 1932 [65] and further developed by NASA in the 1950s and has been known as "solid smoke" (the lowest density solid known). It is composed of air above $90 \%$ and silica nanoparticles having the lowest thermal conductivity of any solid (around $0.01 \mathrm{~W} / \mathrm{mK}$ ). Aerogel insulation is non-flammable, not carcinogenic [66] and does not release toxic fumes during fire [67]. The first and most known aerogel insulation materials are the insulation blankets produced by Aspen Aerogels (Fig. 4). BASF developed a polyurethane based aerogel that was used to produce insulation boards under the commercial name SLENTITE. Super slim aerogel insulation boards are also commercially available under the name STO therm In Aevero [69]. Filate [68] showed that the application of only $50 \mathrm{~mm}$ thick SLENTITE Aerogel insulation board on the external wall of a telegraph building constructed in the years 1906-1907 (Karlsruhe, Germany) has improved the heat loss through walls by $71 \%$. The floor retrofitting of the aforementioned building also used a ThermablokSP Aerogel insulation flooring board covered with rigid magnesium silicate which was developed by Acoustiblok UK Limited. Aerogel based renders have also merit recent investigations. Kim et al. [70] have studied the insulation performance of aerogel cement prepared with aerogel powder and cement paste. A reduction of thermal conductivity was achieved with only $2 \%$ of aerogel. Other authors [71] showed that the use of a $5 \mathrm{~mm}$ aerogel based plaster layer applied to the walls of a building in Italy led to a $2{ }^{\circ} \mathrm{C}$ temperature reduction when compared to the performance of the same building when using traditional plasters. The render manufacturer Fixit AG with the help of the Swiss Federal Laboratories for Materials Science and Technology have developed an aerogel insulating plaster named "Fixit 222 Aerogel" with the thermal conductivity of $28 \mathrm{~mW} 7(\mathrm{mK})$ [72]. However, the cost of this material is about $80 € / \mathrm{m}^{2}$ considering a thickness of $10 \mathrm{~mm}$ of the coat. This cost is much higher than the ones of traditional plasters (Table 1). However, ongoing research is expected to cut down the cost of aerogel by half in 2020. Since the majority of energy losses in a building occur through windows the improvement in windows thermal performance is crucial for building energy efficiency. Traditional double glazed windows show a thermal transmittance around $\mathrm{U}=3 \mathrm{~W} / \mathrm{m}^{2} \mathrm{~K}$ and the best commercial solution can go down to $\mathrm{U}=1 \mathrm{~W} / \mathrm{m}^{2} \mathrm{~K}$. Aerogel based windows are very promising high tech alternatives. Not only do they have a much lower mass (as much as 10 times lower [74]) but they also show a thermal transmittance of around $0.5 \mathrm{~W} / \mathrm{m}^{2} \mathrm{~K}$. This value can, additionally, be reduced even further [75]. Fig. 5 compares monolithic aerogel and granular aerogel glazings. The former has a higher light transmittance and lower U-values. Buratti and Moretti [76,77] compared the performance of seven different glazings and found that granular aerogel glazing was the most efficient system especially for cold climates leading to an annual energy demand decrease of about $10-20 \%$ when compared to the standard glazings. The advantages in using aerogel glazing have been recently confirmed by other authors $[78,79]$. However, as some authors [80] reported that the cost of an aerogel window could be six times higher than a conventional window this is a challenge that needs to be overcome. A very recent study [81] showed that, replacing the double glazed windows with nanogel glazing in a multi-storey office building located in Dhahran, achieved a saving of $14 \%$ in the annual energy consumption of the building. It's important to mention that the 

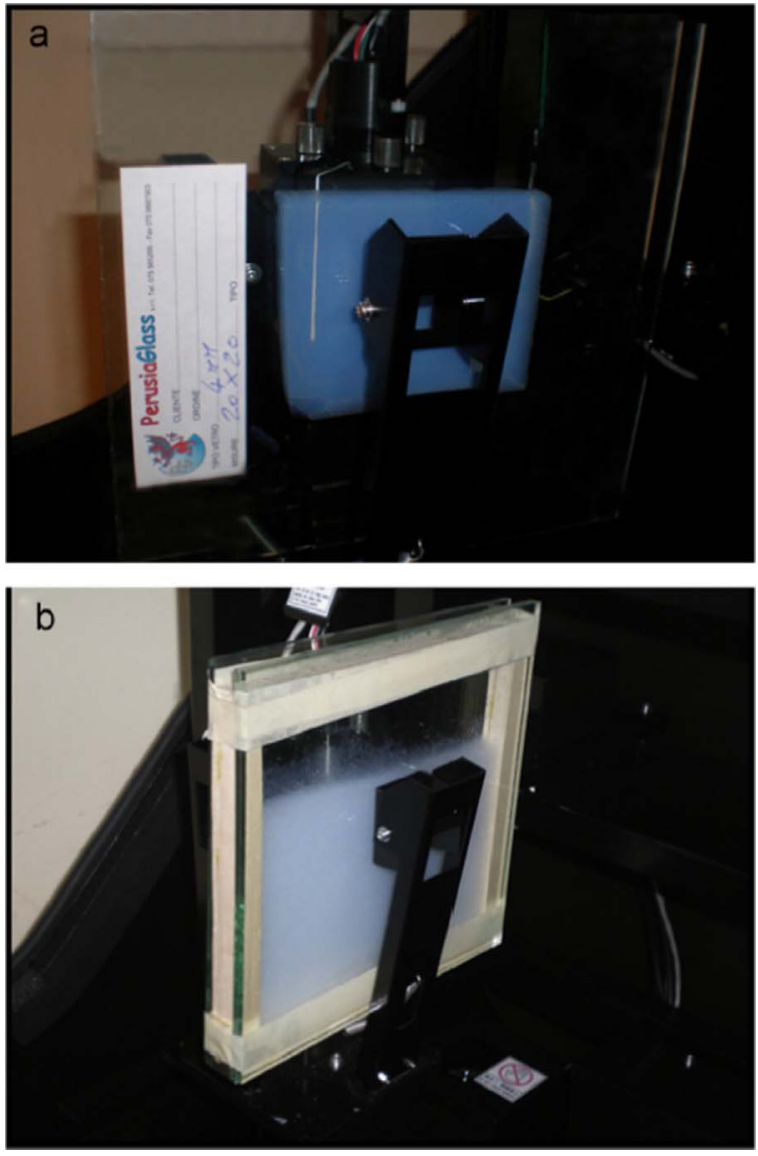

Fig. 5. (a) Monolithic aerogel and(b)granular aerogel glazings [76].

economic analysis was based on a cost of $322 \mathrm{USD} / \mathrm{m}^{2}$ for the nanogel glazing which is just $10 \%$ above the cost of double glazed windows. Furthermore, the eco-efficiency of aerogel windows still remains to be proven by life cycle assessment investigations. Nanotechnology can also be used to enhance the performance of phase change materials (PCMs). These materials use chemical bonds to store or release heat hence reducing energy consumption. Depending on the air temperature PCMs can change from solid to liquid or liquid to solid, absorbing or releasing heat during the process. Therefore, they can absorb heat inside buildings avoiding excessive heating and reducing cooling needs. The development of nanoencapsulated phase change materials for

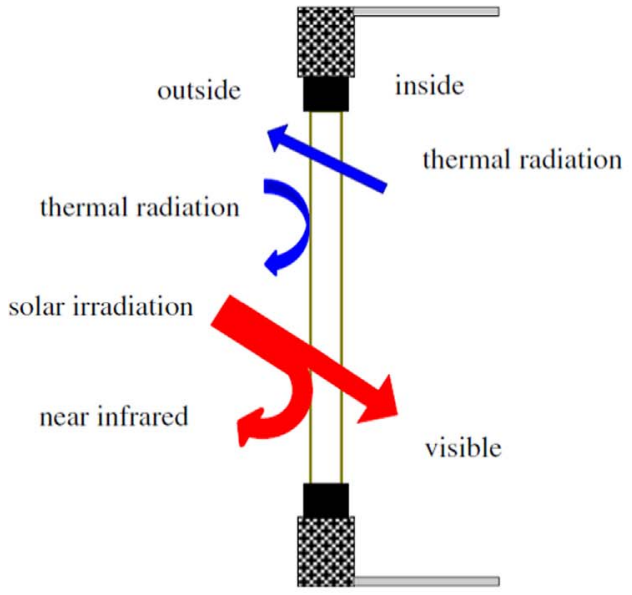

(a) Perfect window for summer façades components is also important for building energy efficiency. This research line was mentioned by the High level group on KETs on the nanotechnology report [82]. Several authors have reported promising results in this field allowing for enhanced heat transfer characteristics and energy efficiency [83-87]. Though nanoencapsulation of PCMs may have a potential to improve PCM materials it has not yet been used in commercial products [88]. Not to mention that cost analysis and economic evaluations constitute a gap in the studies of buildings with PCMs [89]. Besides, this author thinks that concerning PCM materials the high number of existent commercial producers and the relatively modest energy efficiency gains associated to these materials are relevant limitations to startup creation. Another high priority research line concerns the development of cool materials incorporating new advanced nano-materials [90]. Cool materials have high solar reflectance (high albedo or low emissivity) allowing for the reduction of energy cooling needs in summer. Jelle et al. [91] provides a good review concerning these materials. Two main limitations characterized cool materials. The decrease in visible transmittance is one and the other is the durability of the thermal-optical and radiative properties. A few nanotech investigations have been made regarding both. Some by using anti-reflection coatings to increase the visible transmittance [92]. Other authors [93] reported investigations on a reflective geopolymeric coating based on titanium dioxide hollow glass microspheres with a reflectance exceeding $90 \%$ and high durability. Also the Cool-Coverings FP7 project [94] whose aim is the development of a novel and costeffective range of nanotech improved coatings to substantially improve near infrared reflective properties constitutes a very interesting ground for the creation of startups. Also crucial for energy efficient buildings are switchable glazing technology based materials. This technology regulates the solar spectrum which is a necessary requisite for achieving perfect window status (Fig. 6).The perfect window for summer has no absorbability in solar spectrum while the perfect window for winter is totally transparent to the entire solar spectrum. Some authors $[96,97]$ consider switchable windows a promising technology on the recent concept of climate adaptive building shells capable of operating in harmony with Nature and others state they have the largest potential to minimize the energy use in buildings and allow for the nearly Zero Energy Building target [98]. Switchable glazing technology refers to materials and devices that make it possible to construct glazings whose throughput of visible light and solar energy can be switched to different levels depending on the application of a low DC voltage (electrochromics) or on the temperature (thermochromics) or even by using hydrogen (gasochromics). Electrochromic windows have shown a 54\% energy reduction in

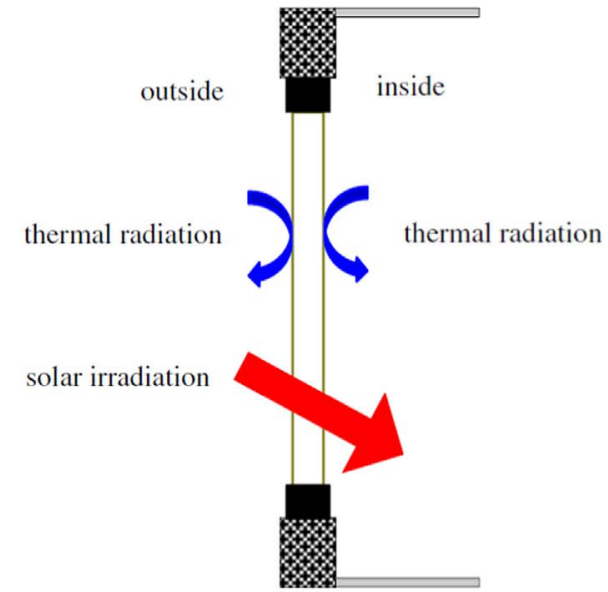

(b) Perfect window for winter

Fig. 6. Schematic diagram of the perfect windows [95]. 

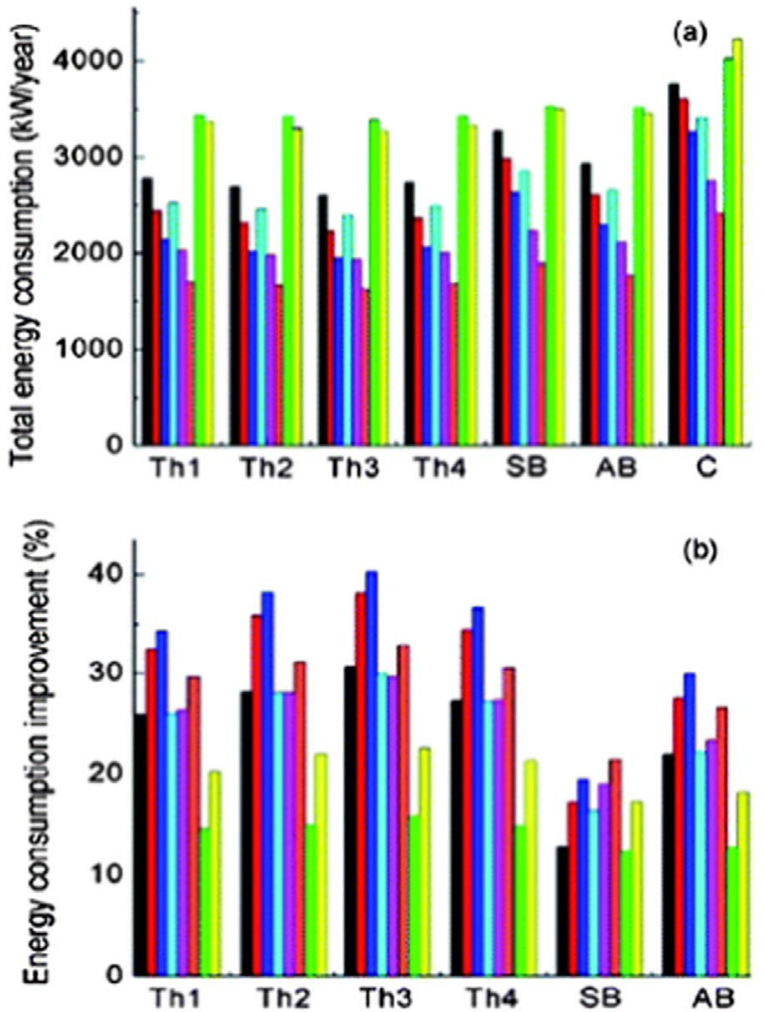

Fig. 7. Total annual energy consumption (a) and percent improvement compared to a clear glazing (b) for different glazings. Color coding: black (Cairo), red (Palermo), dark blue (Rome), light blue (Milan), violet (Paris), orange (London), green (Moscow) and yellow (Helsinki) [101]. (For interpretation of the references to color in this figure legend, the reader is referred to the web version of this article.)

electrochromic windows when compared to standard single glazed windows for a 25 years life cycle [99]. Other authors [100] have studied gasochromics windows reporting a $34 \%$ reduction on cooling needs when compared to standard double glazed windows. Saeli et al. [101] have studied the performance of several types of thermochromic coatings: a $\mathrm{VO}_{2}$ film (Th1), such a film with the inclusion of some gold nanoparticles in order to affect the colour (Th2), a $\mathrm{VO}_{2}$ film with a growth-directing surfactant (Th3), and a film with both gold nanoparticles and surfactant (Th4). It has also been studied the glass with a sputter deposited silver-based "solar control" film which transmitted most of the visible light but reflected near-infrared solar radiation ("Suncool Brilliant", SB) and a blue body-tinted glass ("Arctic Blue”, AB). Simulations with plain float glass (denoted C) served as a baseline. The environment was taken to represent Cairo (Egypt), Palermo, Rome and Milan (Italy), London (UK), Helsinki (Finland) and Moscow (Russia). Fig. 7 shows the total annual energy consumption and percent improvement compared to a clear glazing that peaks at Rome conditions (Th3). Pittaluga et al. [102] have studied an innovative use of electrochromic glazing in a dynamic wall that in the winter works like a Trombe wall, and in the summer works as a ventilated façade. They reported that the use of electrochromic glass allow energy cooling savings of 22\% (Fig. 8). Tavares et al. [103] have reported savings of about $14 \%$ in the annual energy needs resulting by single glass replacement with double electrochromic glass controlled by solar radiation. According to these authors for this energy savings, the maximum permissible additional cost per $\mathrm{m}^{2}$ of EC glass, to a simple recover period of 10 years is $33.44 €$ (Table 2). Several comercial solutions are already available on the market (SAGE ElectrochromicsUSA, Econtrol Glas, Saint Gobain Sekurit and Gesimat-Germany, amongst others) with a service life of 30 years and capable of 100 , 000 switching cycles. ChromoGenics was established in 2003 as the outcome of over 20 years of research on electrochromic materials by
Professor Claes-Göran Granqvist and his team at the Ångström Laboratory at Uppsala University in Sweden. Using a laminated electrochromic plastic foil, ConverLight ${ }^{\mathrm{TM}}$, rather than coating the glass itself ChromoGenics can contribute to more scalable and costeffective smart glass manufacturing [104]. The most challenging point of smart windows at the moment is their higher cost compared to the other glazing technologies [105]. Hee et al. [106] states that due to the higher costs of dynamic glazing, it is more suitable to be installed in building which needs high performance in terms of daylighting and energy saving such as commercial buildings. However, it is expected that in the next years, higher performance and lower cost switchable glazing windows will be available [107]. Recent investigations [108] show promising new cost-effective methods to fabricate thermochromic $\mathrm{VO}_{2}$ films for smart windows. It's important to stress that the market for this products is predicted to increase from current $\$$ 84 million to $\$ 700$ million by 2020 [109].

\section{Biotechnologies for energy efficient built environment}

Biotechnology is one of the world's fastest growing industries. As such, it could become, in the future, a hot area allowing for radical changes in the eco-efficiency of construction materials and technologies. As biotechnology is one of the six Key Enabling TechnologiesKETs that will be funded by the EU Framework Programme Horizon 2020 [110] this can also foster the development of start-ups in the field of bio materials and technologies for energy efficient built environment. These may include the use of admixtures based on renewable bio-based feedstocks and or capable of biodegradation to replace chemical admixtures. Last years have been marked by a tremendous increase in the number of publication citations on bio based polymers (around $1000 \%$ in the last 10 years). However, these materials still constitute a very small fraction of the polymer industry [111]. Biopolymers include polymers from agro-resources (polysaccharides, cellulose, starch, chitin, chitosan and alginates), from microorganisms by fermentation (polyhydroxyalkanoates, PHA, PHB) and from biotechnology via conventional synthesis (Polylactides, PBS, PE, PTT, PPP) [112]. Biotech admixtures processes made in fermentation processes by employing bacteria [113] or fungi seem to receive an increasing attention. Furthermore, their biosynthesis rate is about 2-4 times higher than that of plant based biopolymer [114]. Although, some are biodegradable that is not always the case like, for instance, biopolyhethylene (PE). Investigations concerning the use of renewable energy for the production of biopolymers are needed to reduce the environmental impact of the production stage [115]. It is clear that the farming practices used to grow bio based feedstocks including the fuel required for plowing, harvesting, manufacture, transport and the use of herbicides and pesticides can also have high environmental impacts as high as those of petrochemical based polymers $[116,117]$. However, biopolymers are not associated to armed conflicts nor are they responsible for large environmental disasters that so often occur in crude oil extraction and transportation. Besides, the reuse of agricultural and biomass waste will also contribute to enhance the environmental advantages of biopolymers over traditional petroleum-based polymers $[118,119]$. The nanotech advancements that have occurred in the last decade will allow for the development of new and improved biopolymer based materials. Investigations on cellulose nanocrystals (cellulose elements having at least one dimension in the $1-100 \mathrm{~nm}$ range) are an important and recent nanotech field that will enable the development of eco-efficient high performance materials [120,121]). The potential of nanocellulose materials can be perceived from the increase in the number of papers published in this scientific field. According to Mariano et al. [122] the number of papers in this area is expected to increase by a further $500 \%$ at least by 2017 , leading to an increase in perspective production in the range of $1000 \%$ in the next two years. However, the transition from advanced research to practical applications for the built environment is likely to take several years to 


\section{Total Energy consumption}

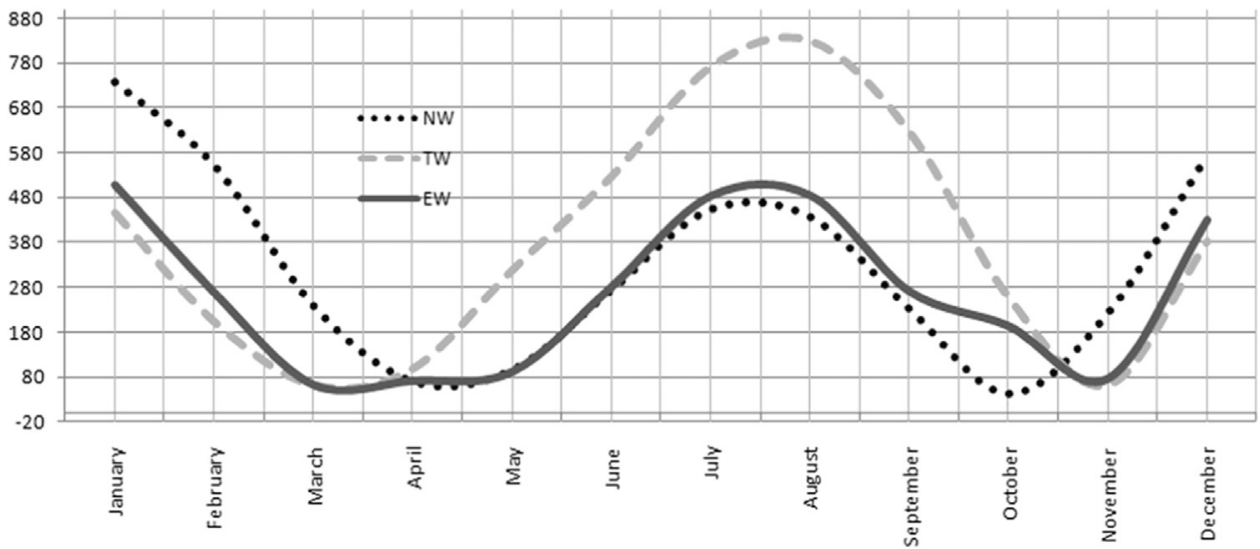

Fig. 8. Comparison of the total energy consumption in the three models (normal wall-NW, Trombe wall-TW, and electrochromic wall-EW) [102].

Table 2

Simplified economic analysis of possible additional costs for electrochromic glass [103].

\begin{tabular}{|c|c|c|}
\hline \multicolumn{2}{|l|}{ Heating energy saved from the use of EC glass } & $700 \mathrm{kWh}$ \\
\hline \multicolumn{2}{|l|}{ Cooling energy saved from the use of EC glass } & $8911.27 \mathrm{kWh}$ \\
\hline \multicolumn{2}{|c|}{ Annual energy savings resulting from the use of EC glass } & 9611.91 \\
\hline \multicolumn{2}{|c|}{ EC glass area } & $402.46 \mathrm{~m}^{2}$ \\
\hline \multicolumn{2}{|l|}{ Annual energy saved per unit area } & $\begin{array}{l}23.88 \mathrm{kWh} / \mathrm{m}^{2} \mathrm{EC} \\
\text { glass.year }\end{array}$ \\
\hline \multirow{2}{*}{\multicolumn{2}{|c|}{$\begin{array}{l}\text { kWh price } \\
\text { Without considering power rate and taxes }\end{array}$}} & 0.14 euro \\
\hline & & \\
\hline \multirow{5}{*}{$\begin{array}{l}\text { Maximum additional allowable costs (euro/ } \\
\mathrm{m}^{2} \text { ) to recover the investment in EC } \\
\text { windows in: }\end{array}$} & 1 year & 3.34 euro \\
\hline & 5 years & 16.72 \\
\hline & 10 years & 33.44 \\
\hline & 15 years & 50.15 \\
\hline & 20 years & 66.87 \\
\hline
\end{tabular}

be effective. For instance, the production of nanocellulose aerogel thermal insulation materials is an important biotech feature for building energy efficiency [123]. Nguyen et al. [124] reported the production of cellulose aerogels from paper waste. As this material is repellent to water, it can be applied onto the exterior sides of the walls to protect buildings from moisture attack. Paper waste based cellulose aerogels showed a thermal conductivity of $0.029-0.032 \mathrm{~W} /(\mathrm{m} \mathrm{K})$. This is an excellent performance better than current commercial thermal insulators based on polystyrene or polyurethane. Needless to refer that polystyrene, for example contains anti-oxidant additives and ignition retardants, additionally, its production causes the generation of benzene and chlorofluorocarbons. On the other hand, polyurethane is obtained from isocyanates, which are widely known for their tragic association with the Bhopal disaster [125]. Besides, it releases toxic fumes when subjected to fire $[125,126]$. Another important biotech feature for energy-efficient built environment concerns the production of bio-energy trough microalgae photo-bioreactors (PBRs) integrated in façades or roofs. Photosynthetic microalgae use sunlight as their energy, water as their electron source and $\mathrm{CO}_{2}$ as carbon source. The use of microalgae for biofuel production goes back to the 80's [127] and has gained increasing attention due to the need of renewable energies. Contrary to other biofuels sources microalgae have a high oil content and most important show an extremely rapid growth. It doubles their biomass within $24 \mathrm{~h}$ being the fastest growing organisms in the world. This is about 100-200\% higher than any other energy crop [128]. This of course depends on the type of microalgae species [129]. Table 3 shows that microalgae outperform the oil yield of other crops making it an excellent biodiesel source. Also its very low area as percentage of arable land mass means that microalgae production will not be a food competitor as other biodiesel based crops like soybean or rapeseed. It's
Table 3

Comparison of crop dependent biodiesel production efficiencies from plant oils [130].

\begin{tabular}{|c|c|c|c|c|}
\hline Plant source & $\begin{array}{l}\text { Bio-diesel } \\
\mathrm{L} / \mathrm{ha} / \mathrm{yr}\end{array}$ & $\begin{array}{l}\text { Area to produce } \\
\text { global oil } \\
\text { demand (10E6 } \\
\text { ha) }\end{array}$ & $\begin{array}{l}\text { Area required } \\
\text { as \% of global } \\
\text { land mass }\end{array}$ & $\begin{array}{l}\text { Area as \% of } \\
\text { arable land } \\
\text { mass }\end{array}$ \\
\hline Cotton & 325.0 & 15.00 & 100.7 & 756.9 \\
\hline Soybean & 446.0 & 10932.0 & 73.4 & 551.6 \\
\hline Mustard & 572.0 & 8524.0 & 57.2 & 430.1 \\
\hline Seed & 952.0 & 5121.0 & 34.4 & 258.4 \\
\hline Sunflower & 1190.0 & 40.97 & 27.5 & 206.7 \\
\hline Rapeseed & 1892.0 & 2577.0 & 17.3 & 130.0 \\
\hline Jatropha & 5950.0 & 819.0 & 5.5 & 41.3 \\
\hline Oil palm & $12,000.0$ & 406.0 & 2.7 & 20.5 \\
\hline $\begin{array}{l}\text { Algae }\left(10 \mathrm{~g}^{-}\right. \\
2 \text { day }^{-1} \text { at } \\
30 \% \mathrm{TAG})\end{array}$ & & & & \\
\hline $\begin{array}{l}\text { Algae }\left(50 \mathrm{~g}^{-}\right. \\
2 \text { day }^{-1} \text { at } \\
50 \% \mathrm{TAG})\end{array}$ & $98,500.0$ & 49.0 & 0.3 & 2.5 \\
\hline
\end{tabular}

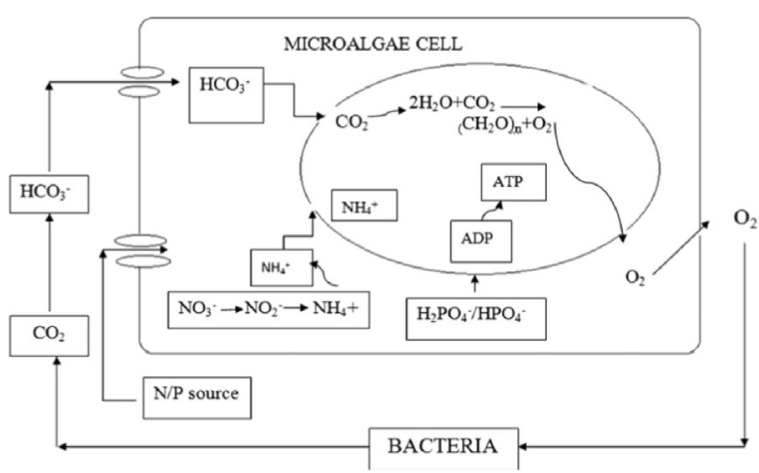

Fig. 9. Bacterial-algae relationship [131].

important to bear in mind that the global biodiesel market average has an annual growth rate of $42 \%$ being estimated to reach about 168 billion litres by 2016 [130]. Still the major constraint to the commercial-scale algae farming for energy production is the cost factor. Even the simplest open pond systems including harvesting and algae biomass processing equipment would cost at least $\$ 100,000$ per hectare [130]. Microalgae have the ability to assimilate nutrients like nitrogen and phosphates (which are present in wastewaters) into the cells for its growth (Fig. 9). Therefore, the application of microalgae for wastewater treatment can be an interesting option to enhance its economic value and at the same time to solve environmental problems 


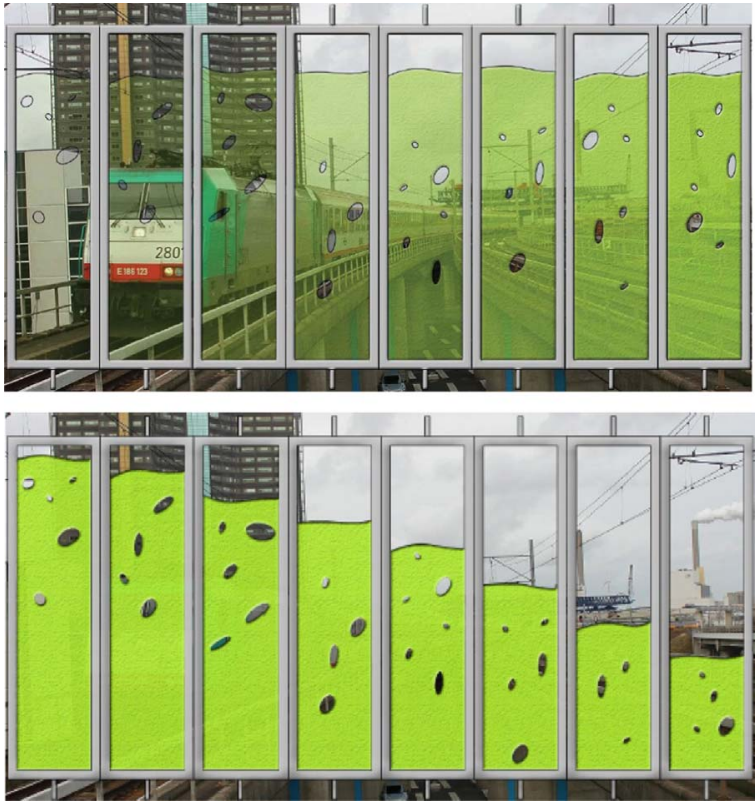

Fig. 10. Flat panel PBRs with different stages of transparency [136].

related to wastewater management. In addition its potential as $\mathrm{CO}_{2}$ abating technology will also increase its cost-efficiency relation. The production of $1 \mathrm{t}$ of algae biomass results in avoiding $0,5 \mathrm{t}$ of $\mathrm{CO}_{2}$ [132]. Microalgae cultivation can take place in raceway ponds or closed PBRs. The later are less expensive to build and operate but have lower productivity when compared with PRBs. Those can include flat plates, vertical columns, stirred tanks, plastic bags, tubular and even other configurations [133]. Architectural PBRs, are similar to the industrial ones, and in the same way, fulfil the function of cultivating microalgae, the innovation is its integration into architecture [134]. Different types of microalgae with different colours, flat panel PBR with different algae concentration or with different water levels (Fig. 10) can provide dynamic shading for buildings. Since low light conditions lead to negative biomass production due to an effect termed dark respiration this means that during the night PBRs require artificial light. Since maximum productivity is attained with a temperature of $20-30{ }^{\circ} \mathrm{C}$ this means that PBRs for buildings located in countries with warmer temperatures will require cooling while heating will be needed in countries with colder conditions. Buzalo et al. [135] analysed the problem of shape optimization of an architectural shell with photobioreactors using an algorithm that takes into account shading from neighbouring buildings and provides the maximization of the specific growth of microalgae biomass. Algae production technologies are quite mature but presently only its application for bio-fixation, especially wastewater treatment is economically feasible. A recent study shows that the use of alkaline media has much higher cost-effectiveness than previous techniques (Fig. 11). Biofuel production from microalgae will

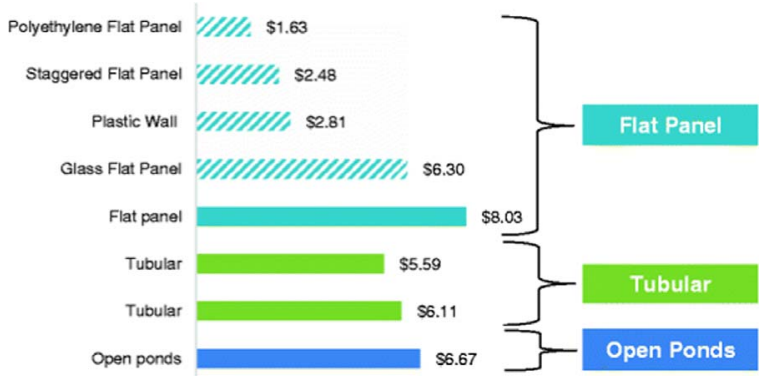

Fig. 11. Production cost in USD per kilogram calculated for the alkaline system and compared with values reported in literature for regular $\mathrm{pH}$ [137].

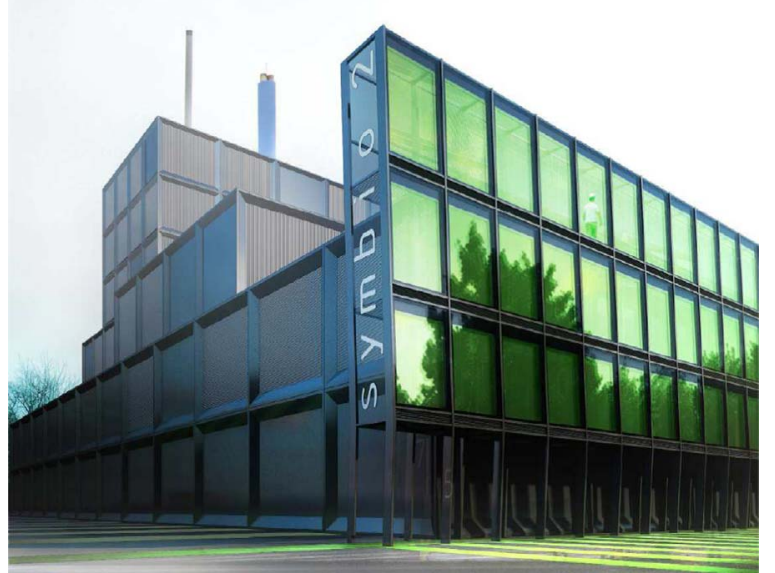

Fig. 12. Waste incineration processing plant with $300 \mathrm{~m}^{2}$ biofacade $P B R$ in Nantes.

become competitive in the medium term if considered along with production of higher value co-products such as bio-fertilizers, biopolymers and others like nanocellulose [130]. Also when associated with carbon intensive operations such as power plants it could reap the advantages of being a carbon-negativ process. Still some recent LCA shows that biofuels generated via cultivation of microalgae in PBR require upgrading [138,139]. As to architectural PBRs it will also contribute to increase the add-value of microalgae production. Fig. 12 shows the waste incineration processing plant with $300 \mathrm{~m}^{2}$ biofacade PBR in Nantes. Although more investigations are needed to optimize (PBRs) integrated in facades or roofs this has high potential for startup creation for the energy efficient built environment.

\section{Conclusions}

The civil engineering area has long been known for not being associated with high tech startup creation. This is a sign of the low innovation which is confirmed by its low patenting level thus contributing to undermine the prestige of this area. Still this domain has an important role to play given the environmental impacts of the construction industry that will be exacerbated in the next decades due to the growth in world population, each day there are about 220,000 new inhabitants each day and that means there will be more than 9,7 billion people by 2050 and 11,2 billion by 2100 . A direct consequence of such growth relates to a steady increase in energy consumption which is the source of two-thirds of global greenhouse-gas emissions. The building sector is responsible for an high energy consumption and its global demand is expected to grow in the next decades. Between 2010 and 2050 the global heating and cooling needs are expected to increase $70 \%$ in residential buildings and $90 \%$ in commercial buildings. Major energy efficiency measures are therefore crucial to reduce energy consumption and greenhouse-gas emissions of the building sector. This includes development of new technologies and materials to greatly improve energy efficiency. Since information derived from knowledge is critical for individuals to transform innovative ideas into commercial products and services, this paper highlights recent developments on nano and biotech innovations important for energy efficient built environment. This review may contribute to enhance the innovation and patenting activity in civil engineering that may help fostering the creation of high tech startups for energy efficient built environment. Aerogel is a perfect example of a nanotech high performance thermal insulation material and some aerogel based renders are already available in the market. However, they have a cost which is much higher than the ones of traditional plasters. Also aerogel based windows constitute a promising high tech alternative to traditional windows. Not only do they have a much lower mass (as much as 10 times lower) but they also show a much lower thermal transmittance. 
However, the cost of an aerogel window could be up to six times that of a conventional window being the main barrier that need to be overcome in the near future for a wide-scale use. Also the eco-efficiency of aerogel windows still remains to be proven by life cycle assessment investigations. The development of cool materials incorporating new advanced nano-materials is an important area concerning building energy efficiency. Two main limitations characterize cool materials. The decrease in visible transmittance is one and the other is the durability of the thermal-optical and radiative properties. The recent CoolCoverings FP7 project which aims at the development of a novel and cost-effective range of nanotech improved coatings to substantially improve near infrared reflective properties constitutes a very interesting ground for the creation of startups. Switchable glazing technology based materials are also important for building energy efficiency and start up creation. Several commercial solutions are already available on the market with a service life of 30 years and capable of 100,000 switching cycles. However, its most challenging aspect is their higher cost. Therefore some authors state that in the meantime this technology should be installed in the buildings which need high performance in terms of daylighting and energy saving such as commercial buildings. The Swedish company ChromoGenics started using a laminated electrochromic plastic foil rather than coating the actual glass thus being able to contribute to more scalable and cost-effective smart glass manufacturing. Also recent investigations show promising new costeffective method to produce thermochromic $\mathrm{VO}_{2}$ films for smart windows. Therefore it is foreseeable that in the next years, higher performance and lower cost switchable glazing windows will be available. Another important biotech feature for energy-efficient built environment concerns the production of bio-energy trough microalgae photo-bioreactors integrated into facades or roofs. Photosynthetic microalgae use sunlight as their energy, water as their electron source and $\mathrm{CO}_{2}$ as carbon source. Algae production technologies are quite mature but presently only its application for bio-fixation, especially wastewater treatment is economically feasible. Biofuel production from microalgae will become competitive in the medium term if considered along with production of higher value co-products such as biofertilizers, biopolymers and others like nanocellulose and also associated to carbon intensive operations such as power plants it could reap the advantages of being a carbon-negative process. So far many nano and bio based materials and technologies for energy efficient built environment have been developed. Nanomaterials are associated with occupational risks that still need to be tackled. Also the LCA of most is not environmental friendly and for some it is still an open issue. Furthermore, cost effectiveness is still far from being attained. Therefore, development of scalable nano and bio based materials and technologies are essential to overcome that gap. Startup creation may be used as a means to raise the dynamics and obtain the funding needed to achieve that goal.

\section{Acknowledgments}

The authors would like to acknowledge the financial support of the Foundation for Science and Technology (FCT) in the frame of project IF/00706/2014-UM.2.15.

\section{References}

[1] Rothe C. Using patents to advance the civil engineering profession. Civil Eng 2006:67-73.

[2] Keefe S. Patent eligibility: an open fieled for civil engineering. Civil Eng 2012:70-3.

[3] Fisch C, Hassel T, Sandner P, Block J. University patenting: a comparison of 300 leading universities worldwide. The J of Technology Transfer 2014, in press.

[4] Byfield MP. British civil engineering skills: Defusing the time bomb. Proc Inst Civil Eng: Civil Eng 2003;156(4):183-6.

[5] Lawless A. A wake up call to address the capacity crisis in SA civil engineering. Civil Eng/Siviele Ingenieurswese 2005;13(10):40-3

[6] Hubbard BJ, Hubbard SM. Activities to enhance civil engineering recruitment and coordination with industry. Transp Res Record 2009:22-30.

[7] Quapp U, Holschemacher K, Efforts to reduce the drop-out rate in civil and structural engineering programs. Research and applications in structural engineering, mechanics and computation. In: Proceedings of the 5th international conference on structural engineering, mechanics and computation, SEMC; 2013. p. $2545-8$

[8] F. Pacheco-Torgal. Introduction to the start-up creation for the smart eco-efficient built environment. In Start-up creation: The smart eco-efficient built environment , ed. Pacheco-Torgal, Rasmussen, Granqvist, Ivanov, Kaklauskas and Makonin, Woodhead Publishing Ltd- Elsevier Science and Technology, Abington Hall, Cambridge, UK, 2016, pp. 1-15.

[9] Nehdi M. Crisis of civil engineering education in information technology age: analysis and prospects. J Prof Issues Eng. Educ. Pract. 2002;128(3):131-7.

[10] Chakraborty S, Iyer N, Krishna P, Thakkar S. Assessment of civil engineering inputs for infrastructure development. Ind Natl Acad Eng 2011.

[11] Hamill L, Hodgkinson L. Civil engineering's image in schools - and how to change it. In: Proceedings of the ICE - Civil Engineering, Vol. 156, Issue 2; 2003. p. 7885 .

[12] Fulford R, Standing C. Construction industry productivity and the potential for colaborative practice. Int J Project Manag 2014;32(2):315-26.

[13] Morby A. Cost rises squeeze builders profit margins. Construction enquirer, $10 \mathrm{de}$ Fevereiro; 2014

[14] McKinsey . How to build a skyscraper in two weeks. Insigths Publ 2014 〈http:// www.mckinsey.com/insights/engineering construction/how to build a skyscraper_in two_weeks $\rangle$.

[15] WHO Urban population growth. Global health observatory 2014. 〈http://www. who.int/gho/urban_health/situation_trends/urban_population_growth_text/ en/ $\rangle$.

[16] Seto KC, Buneralp B, Hutyra LR. Global forecasts of urban expansion to 2030 and impacts on biodiversity and carbon pools. PNAS 2012:17-21.

[17] Baumol WJ. Small enterprises, large firms, productivity growth and wages. J Policy Model 2008;30(4):575-89.

[18] Schmid G. Youth unemployment in India: from a European and transitional labour market point of view. IZA Policy Paper No. 95. Bonn, Germany: Institute for the Study of Labor; 2015.

[19] Min W. The challenge facing Chinese higher education in the next two decades. Int Higher Educ 2015;80:11-2.

[20] COM 571. final Roadmap to a Resource Efficient Europe; 2011.

[21] Krausmann F, Gingrich S, Eisenmenger N, Erb K-H, Haberl H, Fischer-Kowalski M. Growth in global materials use, GDP and population during the 20th century. Ecolog Econ 2009;68:2696-705.

[22] Allwood J, Ashby M, Gutowski T, Worrell E. Material efficiency: a white paper. Res, Conserv Recycling 2011;55:362-81.

[23] Whitmore A. The emperor's new clothes: Sustainable mining. J Cleaner Prod 2006;14:309-14.

[24] Flatt R, Roussel N, Cheeseman CR. Concrete: An eco-material that needs to be improved. J Eur Ceram Soc 2012;32(11):2787-98.

[25] Gartner E, Macphee D. A physico-chemical basis for novel cementitious binders. Cement Concr Res 2011;41:736-49.

[26] Shi C, Fernandez-Jimenez A, Palomo A. New cements for the 21st century: The pursuit of an alternative to Portland cement. Cement Concr Res 2011;41:750-63.

[27] Pacheco-Torgal F, Jalali S. Eco-efficient construction and building materials. London, UK: Springer Verlag; 2011.

[28] Davalos JF. Advanced materials for civil infrastructure rehabilitation and protection. New York: Seminar at The Citty College of New York; 2012.

[29] NCL. 〈http://www.ncl.ac.uk/press.office/press.release/item/infrastructure-planis-good-news-for-civil-engineers-of-the-future $\rangle ; 2012$.

[30] Amouroux J, Siffert P, Massue JP, Cavadias S, Trujillo B, Hashimoto K, Rutberg P, Dresvin S, Wang X. Carbon dioxide: A new material for energy storage. Progress Nat Sci: Mater Int 2014;24:295-304.

[31] King D, Browne J, Layard R, O’ Donnell G, Rees M, Stern N, Turner A. A global Apollo programme to combat climate change; 2015.

[32] WEO/IEA. World energy outlook . Executive summary. Paris: International Energy Agency; 2013. p. 2013.

[33] IPCC . Summary for policymakers. In: Field CB, Barros VR, Dokken DJ, Mach KJ, Mastrandrea MD, Bilir TE, Chatterjee M, Ebi KL, Estrada YO, Genova RC, Girma B, Kissel ES, Levy AN, MacCracken S, Mastrandrea PR, White LL, editors. Climate Change 2014: impacts, adaptation, and vulnerability. Part A: global and sectoral aspects. contribution of working group II to the fifth assessment report of the intergovernmental panel on climate change. Cambridge, United Kingdom and New York, NY, USA: Cambridge University Press; 2014. p. 1-32.

[34] Ürge-Vorsatz D, Cabeza L, Serrano S, Barreneche C, Petrichenko K. Heating and cooling energy trends and drivers in buildings. Renew Sustain Energy Rev 2015;41:85-98.

[35] UNFCCC . Compilation of information on mitigation benefits of actions, initiatives and options to enhance mitigation ambitionUNFCCC document FCCC/TP/2013/. Geneva: United Nations Office at Geneva; 2013. p. 4.

[36] Lechtenbohmer S, Schuring A. The potential for large-scale savings from insulating residential buildings in the EU. Energy Effic 2011;4:257-70.

[37] Copiello S. Building energy efficiency. A research brand made of paradoxes. Renew Sustain Energy Rev 2016, in press.

[38] Xing Y, Hewitt N, Griffiths P. Zero carbon buildings refurbishment--A Hierarchical pathway. Renew Sustain Energy Rev 2011;15:3229-36.

[39] Atanasiu B, Knotonasiou E, Mariottini F. Alleviating fuel poverty in the EU. Investing in home renovation. A sustainable and inclusive solution. Brussels: Buildings Performance Institute Europe; 2014, (BPIE). 
[40] JCR. Energy Renovation: The Trump Card for the New Start for Europe. Joint Research Centre, Institute for Energy and Transport Luxembourg; 2015.

[41] Bras A, Rocha A, Faustino P. Integrated approach for school buildings rehabilitation in a Portuguese city and analysis of suitable third party financing solutions in EU. J Build Eng 2015;3:79-93.

[42] Drexler K. Molecular engineering: an approach to the development of general capabilities for molecular manipulation. Proc Natl Acad Sci USA 1981;78:5275-8.

[43] Zheng W, Shih H, Lozano K, Mo Y. Impact of nanotechnology on future civil engineering practice and its reflection in current civil engineering education. J Prof Issues Eng. Educ. Pract. 2011;137(3):162-73.

[44] Mangematim V, Walsh S. The future of nanotechnologies. Technovation 2012;32:157-60.

[45] Rieke V, Bachmann G. German innovation initiative for nanotechnology. J Nanoparticle Res 2004;6:435-46.

[46] Soltani A, Tabatabaeian S, Hanafizadeh P, Soofi J. An evaluation scheme for nanotechnology policies. J Nanoparticle Res 2011;13:7303-12.

[47] Arnall A, Parr D. Moving the nanoscience and technology (NST) debate forwards: short-term impacts, long-term uncertainty and the social constitution. Technol Soc 2005;27:23-38.

[48] Salerno M, Landoni P, Verganti R. Designing foresight studies for Nanoscience and Nanotechnology (NST) future developments. Technol Forecast Soc Change 2008; 75:1202-23.

[49] Wang G, Guan J. The role of patenting activity for scientific research: A study of academic inventors from China's nanotechnology. J Informetr 2010;4:338-50.

[50] Dong H, Gao Y, Sinko P, Wu Z, Xu J, Jia L. The nanotechnology race between China and the United States. Nano Today 2016;11:7-12.

[51] Gao Y, Jin B, Shen W, Sinko P, Xie X, Zhang H, Jia L. China and the United States-Global partners, competitors and collaborators in nanotechnology development. Nanomed: Nanotechnol, Biol, Med 2016;12:13-9.

[52] Serrano E, Rus G, Garcia-Martin J. Nanotechnology for sustainable energy. Renew Sustain Energy Rev 2009;13:2373-84.

[53] Shapira P, Youtie J. The economic contributions of nanotechnology to green and sustainable growth. In: Basiuk V, Basiuk E, editors. Green Processes forNanotechnology. Switzerland, Cham: Springer International Publishing; 2015. p. 409-34.

[54] Bystrzejewska-Piotrowska G, Golimowski J, Urban. P. Nanoparticles: their potential toxicity, waste and environmental management. Waste Manag 2009;2009(29):2587-95.

[55] Pacheco-Blandino I, Vanner R, Buzea C. Toxicity of nanoparticles. In: PachecoTorgal F, Jalali S, Fucic A, editors. Toxicity of building materials. Cambridge, UK: Woodhead Publishing Limited- Elsevier Science and Technology, Abington Hall; 2012. p. 427-75.

[56] Kim J, Rivera J, Meng T, Laratte B, Chen S. Review of life cycle assessment of nanomaterials in photovoltaics. Solar Energy 2016;133:249-58.

[57] Spitzmiller, Mahendra S, Damoiseaux R. Pacheco-Torgal Diamanti, Nazar Granqvist, editors. Safety issues relating to nanomaterials for construction applications. InNanotechnology in eco-efficient construction. Cambridge, UK: Woodhead Publishing Limited- Elsevier Science and Technology, Abington Hall 2013. p. 127-58.

[58] Lopez de Ipina J, et al. Strategies, methods and tools for managing nanorisks in construction. In: 4th International Conference on Safe Production and Use of Nanomaterials (Nanosafe 2014); 2015

[59] Pacheco-Torgal F, Jalali S. Nanotechnology: Advantages and drawbacks in the field of building materials. Construct Build Mater 2011;25:582-90.

[60] Pacheco-Torgal F, Diamanti M, Nazari A, Granqvist CG. Nanotechnology in ecoefficient constructionMaterials, processes and applications.. Cambridge, UK: Woodhead Publishing Limited Abington Hall; 2012.

[61] Weinberger n, Jorissen j, Schipi j. foresight on environmental technologies: options for the prioritisation of future research funding - lessons learned from the project "roadmap environmental technologies 2020. J Clean Prod 2012;27:32-41.

[62] Hussein A. Applications of nanotechnology in renewable energies-A comprehensive overview and understanding. Renew Sustain Energy Rey 2015;42:460-76.

[63] Clements-Croome D. Sustainable intelligent buildings for people: A review. Intell Build Int 2011;3:67-86

[64] Jelle B. Traditional, state-of-the-art and future thermal building insulation materials and solutions - Properties, requirements and possibilities. Energy Build 2011;43:2549-63.

[65] Aerogels Handbook. In: Aegerter Michel A, Leventis Nicholas, Koebel Matthias, (Eds.) Springer Series Advances in Sol-Gel Derived Materials and Technologies. 1st Edition., ISBN: 978-1-4419-7477-8; 2011.

[66] Buratti C, Moretti E. Glazing systems with silica aerogel for energy savings in buildings. Appl Energy 2012;98:396-403.

[67] Baetens R, Jelle B, Gustavsen A. Aerogel insulation for building applications: a state-of-the-art review. Energy Build 2011;43:761-9.

[68] Filate SS. Investigation of an energy refurbishment concept for office building using Nanogel ${ }^{\circledR}$ Aerogel insulation plaster and replaced windows by building simulationMaster Programme in Energy Technology. Uppsala: Uppsala Universitet; 2014

[69] BASF, BASF Polyurethanes. 〈http://www.polyurethanes.basf.de/pu/solutions/en/ content/group/innovation/products/slentite/intro〉.

[70] Kim S, Seo J, Cha J, Kim S. Chemical retreating for gel-typed aerogel and insulation performance of cement containing aerogel. Constr Build Mater 2013;40:501-5.

[71] Buratti C, Moretti E, Belloni E, Agosti F. Development of innovative aerogel based plasters: preliminary thermal and acoustic performance evaluation. Sustainability
2014:6:5839-52.

[72] FIXIT ch AEROGEL Insulating Plaster Fixit AG; 2014. 〈http://www.fixit.ch/ aerogel/?w=daemmputz

[73] Barbero S, Dutto M, Ferrua C, Pereno A. Analysis on existent thermal insulating plasters towards innovative applications: Evaluation methodology for a real costperformance comparison. Energy Build 2014;77:40-7.

[74] Schultz J, Jensen K, Kristiansen F. Super insulating aerogel glazing. Sol Energy Mater Solar Cells 2005;89:275-85.

[75] Jelle BP, Hynd A, Gustavsen A, Arasteh D, Goudey H, Hart R. Fenestration of today and tomorrow: A state-of-the-art review and future research opportunities. Sol Energy Mater Solar Cells 2012;96:1-28.

[76] Buratti C, Moretti E. Glazing systems with silica aerogel for energy savings in buildings. Appl Energy 2012;98:396-403.

[77] Buratti C, Moretti E. Chapter 20 -Nanogel windows. In: Torgal FP, Mistretta M, Kaklauskas A, Granqvist CG, Cabeza LF, editors. Nearly Zero Energy Building Refurbishment: A Multidisciplinary Approach. Springer-Verlag London Ltd; 2013.

[78] Wang H, Wu H, Ding Y, Feng J, Wang S. Feasibility and optimization of aeroge glazing system for building energy efficiency in different climates. Int $\mathrm{J}$ LowCarbon Technol 2014:1-8.

[79] Berardi U. The development of a monolithic aerogel glazed window for an energy retrofitting project. Appl Energy 2015;154:603-15.

[80] Cuce E, Cuce PM, Wood CJ, Riffat SB. Toward aerogel based thermal superinsulation in buildings: A comprehensive review. Renew Sustain Energy Rev 2014;34:273-99.

[81] Mujeebu M, Ashraf N, Alsuwayigh A. Energy performance and economic viability of nano aerogel glazing and nano vacuum insulation panel in multi-story office building. Energy 2016;113:949-56.

[82] HLG KET . High level group on KETs. Thematica area, nanotechnology. Nanotechnol: Sustain Basis Compet Growth Europe 2010.

[83] Kalaiselvam S, Parameshwaram R, Harikrishnan S. Analytical and experimental investigations of nanoparticles embedded phase change materials for cooling application in modern buildings. Renew Energy 2012;39:375-87.

[84] Chen ZH, Yu F, Zeng XR, Zhang ZG. Preparation, characterization andthermal properties of nanocapsules containing phase change material n-dodecanol by miniemulsion polymerization with polymerizable emulsifier. Appl. Energy 2012;91:7-12.

[85] Rao Z, Wang S, Peng F. Molecular dynamics simulations of nano-encapsulated and nanoparticle-enhanced thermal energy storage phasechange materials. Int $J$ Heat Mass Transfer 2013;66:575-84.

[86] Parameshwaran R, Kalaiselvam S. Energy efficient hybrid nanocomposite-based cool thermal storage air conditioning system for sustainable buildings. Energy 2013;59:194-214

[87] Parameshwaran R, Kalaiselvam S. Energy conservative air conditioning system using silver nano-based PCM thermal storage for modern buildings. Energy Build 2014;69:202-12.

[88] Kalnæs S, Jelle P. Phase change materials and products for building applications: A state-of-the-art review and future research opportunities. Energy Build 2015;94:150-76.

[89] Akeiber H, et al. A review on phase change material (PCM) for sustainable passive cooling in building envelopes. Renew Sustain Energy Rev 2016;30:1470-97.

[90] Santamouris M, Synnefa A, Karlessi T. Using advanced cool materials in the urban built environment to mitigate heat islands and improve thermal comfort conditions. Sol Energy 2011;85:3085-102.

[91] Jelle B, Kalnæs S, Gao T. Low-emissivity materials for building applications: A state-of-the-art review and future research perspectives. Energy Build 2015;96:329-56.

[92] Gao T, Jelle B, Gustavsen A. Antireflection properties of monodisperse hollow silica nanospheres. Appl. Phys. A 2013;110:65-70.

[93] Zhang Z, Wang K, Mo B, Li X, Cui X. Preparation and characterization of a reflective and heat insulative coating based on geopolymers. Energy Build 2015;87:220-5

[94] Escribano MAB, Keraben Grupo SA. Development of a novel and cost-effective range of nanotech improved coatings to substantially improve NIR (Near Infrared Reflective) properties of the building envelope, FP7 Project 〈http://cordis.europa. eu/project/rcn/94644_en.html); 2013.

[95] Ye H, Meng X, Long L, Xu B. The route to a perfect window. Renew Energy 2013;55:448-55.

[96] Granqvist C-G. Pacheco-Torgal F, Diamanti V, Nazari A, Granqvist CG, editors. Switchable glazing technology for eco-efficient construction. in nanotechnology in eco-efficient construction. Materials, Processes and Applications. Abington Hall, Cambridge, UK: Woodhead Publishing Limited; 2013. p. 236-69.

[97] Loonen R, Trcka M, Costola D, Hensen J. Climate adaptive building shells: stateof-the-art and future challenges. Renew Sustain Energy Rev 2013;25:483-93.

[98] Favoino F, Overend M, Jin Q. The optimal thermo-optical properties and energy saving potential of adaptive glazing technologies. Appl Energy 2015;156:1-15.

[99] Papaefthimiou S, Syrrakou E, Yianoulis P. Energy performance assessment of an electrochromic window. Thin Solid Films 2006;502:257-64.

[100] Yoshimura K, Yamada Y, Bao S, Tajima K, Okada M. Preparation and characterization of gasochromic switchable-mirror window with practical size. Sol Energy Mater Solar Cells 2009:2138-42.

[101] Saeli M, Piccirillo C, Parkin IP, Binions R, Ridley I. Energy modelling studies of thermochromics glazing. Energy Build 2010;42:1666-73.

[102] Pittaluga M. Electrochromic glazing and walls for reducing building cooling needs. In: Pacheco-Torgal F, Labrincha JA, Cabeza LF, Granqvist CG, editors. Ecoefficient materials for mitigating building cooling needs: Design, properties and applications. UK: Woodhead, Cambridge; 2015. p. 473-97. 
[103] Tavares P, Gaspar A, Martins A, Frontini F. Electrochromic windows impact on energy performance of buildings in Mediterranean climates: A case study. In: Pacheco-Torgal F, Labrincha JA, Cabeza LF, Granqvist CG, editors. Eco-efficient materials for mitigating building cooling needs: Design, properties and applications. UK: Woodhead, Cambridge; 2015. p. 499-524.

[104] ChromoGenics 〈http://www.chromogenics.com/〉

[105] Cuce E, Riffat S. A state-of-the-art review on innovative glazing technologies. Renew Sustain Energy Rev 2015;41:695-714.

[106] Hee W, Alghoul M, Bakhtyar B, Elayeb O, Shameri M, Alrubaih M, Sopian K. The role of window glazing on daylighting and energy saving in buildings. Renew Sustain Energy Rev 2015;42:323-43.

[107] Baetens R, Jelle B, Gustavsen A. Properties, requirements and possibilities of smart windows for dynamic daylight and solar energy control in buildings: A state-of-the-art review. Sol Energy Mater Sol Cells 2010;94:87-105.

[108] Zhang H, Xiao X, Lu X, Chai G, Sun Y, Zhan Y, Xu G. A cost-effective method to fabricate $\mathrm{vo}_{2}(\mathrm{~m})$ nanoparticles and films with excellent thermochromic properties. J Alloys Compd 2015;636:106-12.

[109] Pike Research . Smart glass-electrochromic, suspended particle, thermochromic, and liquid crystal glass technologies for architectural and transportation applications. GlobMarket Anal Forecast 2012.

[110] Pacheco-Torgal F. Eco-efficient construction and building materials research under the EU Framework Programme Horizon 2020. Construct Build Mater 2014;51:151-62.

[111] Babu R, O'Connor K, Seeram R. Current progress on bio-based polymers and their future trends. Prog Biomater 2013;2:8.

[112] Luc A, Eric P. Biodegradable polymersEnvironmental silicate nanobiocomposites. Greenenergy and technology. Hiedelberg: Springer; 2012. p. 13-39.

[113] Pei R, Liu J, Wang s. Use of bactéria cell walls as a viscosity-modifying admixture of concrete. Cement Concr Composites 2015;55:186-95.

[114] Ivanov V, Chu J, Stabnikov V. Basics of construction microbial biotechnology. In: Pacheco-Torgal F, Labrincha J, Diamanti M, Yu C-P, Lee H, editors. Biotechnologies and Biomimetics for Civil Engineering. London: Springer Verlag; 2014.

[115] Guo M, Stuckey D, Murphy R. Is it possible to develop biopolymer production systems independent of fossil fuels? Case study in energy profiling of polyhydroxybutyratevalerate (PHBV). Green Chem 2013;15:706-17.

[116] Yates M, Barlow C. Life cycle assessments of biodegradable, commercial biopolymers-A critical review. Res, Conserv Recycling 2013;78:54-66.

[117] la Rosa AD. LCA of biopolymers. In: Pacheco-Torgal F, Ivanov V, Karak N, de Jonkers H, editors. Biopolymers and biotech admixtures for eco-efficient construction materials.. Cambridge, UK: Woodhead Publishing Ltd- Elsevier Science and Technology, Abington Hall; 2015. p. 57-78.

[118] Gopalakrishnan H, van Leeuwen J, Brown R. Sustainable Bioenergy and BioproductsValue added Engineering and Applications.. Springer; 2012.

[119] Hottle T, Bilec M, Landis A. Sustainability assessments of bio-based polymers. Polym Degrad Stab 2013;98:1898-907.

[120] Charreau H, Foresti M, Vazquez A. Nanocellulose patents trends: A comprehensive review on patents on cellulose nanocrystals, microfibrillated and bacterial cellulose. Recent Pat Nanotechnol 2013;7:56-80.

[121] Chirayil C, Mathew L, Thomas S. Review of recent research in nanocellulose preparation from different lignocellulosic fibers. Rev Adv Mater Sci
2014;37:20-8.

[122] Mariano M, El Kissi N, Dufresne A. Cellulose Nanocrystals and Related Nanocomposites: Review of some Properties and Challenges. J Polym Sci 2014.

[123] Chen W, Li Q, Wang Y, Yi X, Zeng J, Yu H, Liu Y, Li J. Comparative study of aerogels obtained from differently prepared nanocellulose fibers. ChemSusChem 2014;7:154-61.

[124] Nguyen S, Feng J, Ng S, Wong J. Advanced thermal insulation and absorption properties of recycled cellulose aerogels. Colloid Surf A: Physicochem Eng Asp 2014;445:128-34.

[125] Pacheco-Torgal F, Fucic A, Jalali S. Toxicity of building materials. Abington Hall, Cambridge, UK: Woodhead Publishing Limited; 2012.

[126] Liang H, Ho M. Toxicity characteristics of commercially manufactured insulation materials for building applications in Taiwan. Constr Build Mater 2007;21, 125461.

[127] Chisti Y. An unsual hydrocarbon. J Ramsay Soc 1980;27-28:24-6.

[128] Chisti Y. Biodiesel from microalgae. Biotechnol Adv 2007;25:294-306.

[129] Chen C-Y, Yeh K-L, Aisyah R, Lee D-J, Chang J-S. Cultivation, photobioreactor design and harvesting of microalgae for biodiesel production: A critical review. Biores Technol 2011;102:71-81.

[130] Ullah K, Ahmad M, Sharma V, Lu P, Harvey A, Zafar M, Sultana S. Assessing the potential of algal biomass opportunities for bioenergy industry: A review. Fuel $2015 ; 143: 414-23$.

[131] Abinandan S, Shanthakumar S. Challenges and opportunities in application of microalgae (Chlorophyta) for wastewater treatment:A review. Renew Sustain Energy Rev 2015;52:123-32.

[132] Koller M, Salerno A, Braunegg G. Value-added products from algal biomass. In: Perosa A, Bordignon G, Ravagnan G, Zinoviev S, (Eds.) Algae as potential source of food and energy in developing countries: Sustainability, Technology and Selected Case Studies; 2015. p. 19-30.

[133] Liao Q, Li l, Chen R, Zhu X. A novel photobioreactor generating the ligth/dark cycle to improve microalgae cultivation. Biores. Technol. 2014, in press.

[134] Cervera R, Pioz J. Architectural bio-photo reactors: Harvesting microalgae on the surface of architecture. 163-180, I. In: Pacheco-Torgal F, Labrincha J, Diamanti M, Yu C-P, Lee HK, editors. Biotechnologies and biomimetics for civil engineering. London: Springer; 2014.

[135] Buzalo N, Ermachenko P, Bulgakov A, Schach R. Photobiological treatment plants integrated with building's architectural shell. ICSC'15, TheCSCE International Construction Specialty Conference, Vancouver; 2015. p. 443-9.

[136] Fong Q. Algae Architecture. Master thesis in Architectural Engineering. TU Delft, 〈https://oatd.org/oatd/record?record=oai\%5C\%3Atudelft.nl\%5C\%3Auuid\%5C \%3Ab0b6e05d-49d8-4cc0-9e28-f510b0a8b215); 2014.

[137] Canon-Rubio K, Sharp C, Begerson J, Strouss M, Siegler H. Use of highly alkaline conditions to improve cost-effectiveness of algal biotechnology. Appl Microbiol Biotechnol 2016;100:1611-22.

[138] Duta S, Neto F, Coelho M. Microalgae biofuels: A comparative study on technoeconomical analysis and life-cycle assessment. Algal Res 2016;20:44-52.

[139] Monari C, Righi S, Olsen S. Greenhouse gas emissions and energy balance of biodiesel production from microalgae cultivated in photobioreactors in Denmark: a life-cycle modelling. J Clean Prod 2016;112:4084-92.

[140] Betts R, Jones C, Knight J, Keeling R, Kennedy J. El Niño and a record $\mathrm{CO}_{2}$ rise. Nature Climate Change 2016;6:806-10. 